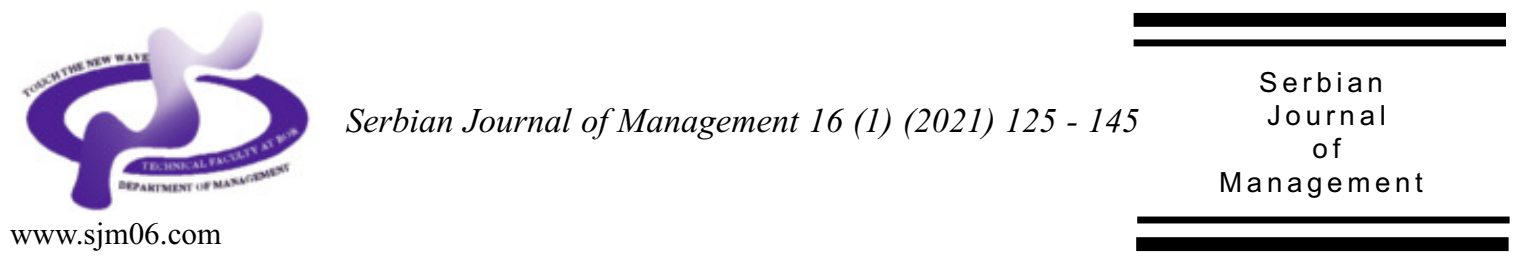

\title{
MODELLING HEALTH CARE CUSTOMER SATISFACTION: EVIDENCE FROM SERBIA
}

\author{
Tamara Rajića ${ }^{*}$, Ana Rakićb and Isidora Miloševićc \\ ${ }^{a}$ Economics Institute, Kralja Milana 16, Belgrade, Serbia

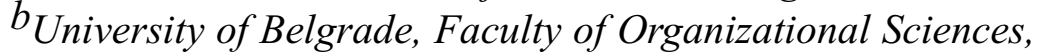 \\ Jove Ilića 154, Belgrade, Serbia \\ ${ }^{c}$ University of Belgrade, Technical Faculty in Bor, Vojske Jugoslavije 12, Bor, Serbia
}

(Received 04 February 2020; accepted 13 August 2020)

\begin{abstract}
Customer loyalty, with satisfaction of customers as its main precondition, has long been regarded as an overarching goal of service businesses. With the proliferation of health care providers, which brought about rising competitive pressures on the market, the issue of how to satisfy and keep patients has been attracting increasing attention of researchers and health care management. Therefore, this study aims to examine the antecedents of patient satisfaction and its direct and mediated impact on patients' behavioural intentions in thus far under-studied context of emerging economy's health care system. The study has been conducted in a primary health care setting, on a convenience sample of 300 patients, by means of structured questionnaire. The application of structural equation modelling (SEM) revealed direct impact of health care service quality on patient satisfaction and its mediated impact on satisfaction, via perceived value of health care services. In addition to direct influence of satisfaction on patients' behavioural intentions, its total effect on positive intentions of patients is increased by the impact of patient commitment to a health care provider, which, as evidenced by this study's findings, increases with patient's rising trust into a health care provider. Implications for theory and practice are discussed and further research directions are provided.
\end{abstract}

Keywords: health care service quality, perceived value, patient satisfaction, trust, commitment, patients' behavioural intentions

\footnotetext{
* Corresponding author: tamara.rajic@ecinst.org.rs
}

DOI: 10.5937/sjm16-25961 


\section{INTRODUCTION}

Recent years have evidenced a trend of a rising influx of private competitors in health care provision. It has been especially observed in health care settings of emerging economies (Pevec \& Pisnik, 2018). Rising competitive pressures have drawn scholarly attention and health care practitioners' interest into the sources of sustainable competitive advantage. Customer satisfaction has been the most frequently recognized pathway towards sustainable competitive advantage.

Patient satisfaction has been shown to bring about important societal and managerial implications. In the study of the quality of surgical care in the U.S. hospitals, Tsai et al. (2015) provided evidence of a strong association between patients' satisfaction and the efficiency of medical care, i.e. the length of stay was shorter after a surgery in hospitals characterized with the highest level of patient satisfaction, as well as readmission rates and mortality rates. Patient satisfaction has been also reported to lead to patients' willingness to actively monitor their health care outcomes and patients' adherence to prescribed therapy and instructions of medical personnel, which have a positive influence on patients' recovery from illness (Sheppard et al., 2008; Dang et al., 2013; Martin et al., 2018; Materla et al., 2019; Huynh \& DickeBohmann, 2020; Ng \& Luk, 2020). On the other hand, it has been shown that low levels of patient satisfaction adversely affect patients' physical, social, functional and overall quality of life (Drury et al., 2020).

The importance of satisfied patients is also grounded on their willingness to recommend health care institution, consider the same institution as their first choice in the future when medical services are needed and tendency to reuse services of the institution which has already provided a service at the satisfactory level (Otani \& Kurz, 2004; Amin \& Nasharuddin, 2013; Aljaberi et al., 2018; Pevec \& Pisnik, 2018; Jameel et al., 2019). Customer behavioural intentions are of primary concern for every service organization, as positive intentions indicate future growth of business, whereas negative intentions are indicators of customer churn. Satisfied patients who spread positive wordof-mouth lower the costs of new patient acquisition and therewith positively affect health care institution's future financial performance (Arasli et al., 2008; Alrubaiee \& Alkaa'ida, 2011; Sumaedi et al., 2016). Moreover, satisfied customers are expected to be willing to pay premium price for services which make them satisfied (Padma et al., 2010). Reputation of a medical institution is also believed to be affected by the level of patients' satisfaction (Pevec \& Pisnik, 2017). Provision of satisfactory health care services has been shown to influence patients' trust into medical institution and its personnel (Alrubaiee \& Alkaa'ida, 2011). It has been reported that patient satisfaction enhances health care institution's image and positively affects its market share (Naidu, 2009).

Numerous empirical evidence across service industries, including health care, points to customer perceptions of service quality as an antecedent to satisfaction (Naidu, 2009; Alrubaiee \& Alkaa'ida, 2011; Chang et al., 2013; Satsanguan et al., 2015, Sumaedi et al., 2016; Aljaberi et al., 2018; Jameel et al., 2019). Although the construct of perceived value has not been extensively studied in a health care setting, some empirical evidence suggests significant impact of health care service quality on 
perceived value of services and positive impact of both constructs on patient satisfaction (Choi et al., 2004; Sumaedi et al., 2016). Service research has suggested relatedness among customer satisfaction and customer behavioural intentions, direct and/or mediated via trust in a provider and commitment to a provider (Kim et al., 2006; Caceres \& Paparoidamis, 2007; Chung \& Shin, 2010; Moreira \& Silva, 2015). Pevec and Pisnik (2018) have also suggested the relevance of trust and commitment to a provider in a health care setting.

However, to the best of our knowledge, the effect of these mediators in a relationship between patient satisfaction and patient behavioural intentions has remained understudied outside of the U.S. and Western European health care settings. Aiming to fill this research gap and contribute to the existing knowledge on the determinants of patient loyalty, this study proposes and empirically investigates a model of patient satisfaction in Serbian primary health care context, taking into account patients' relationships with general practitioners and nursing staff. Conceptual framework of this study builds upon thus far examined antecedents and consequences of customer satisfaction in service businesses, including health care. An examination of an integrative model of patient satisfaction is also expected to bring about managerially relevant knowledge for the administration of health care institutions.

The remainder of the paper is structured as follows. Review of extant literature on the specificity of health care services and antecedents and consequences of customer satisfaction, with special attention to a health care context, is provided first and hypotheses stemming from existing evidence are proposed. Methodological approach is briefly discussed in the following section. Results of the study which has been performed in Serbian health care setting are discussed subsequently. The paper ends with the discussion of the implications of the study and by noting of the study's limitations and suggestions for future research.

\section{LITERATURE REVIEW AND HYPOTHESES}

\subsection{The specificity of health care services}

Health care services evince all unique characteristics of services, such as intangibility, perishability, inseparability of production and consumption and variability of services (Arasli et al., 2008; Berry et al., 2008; Naidu, 2009; Chang et al., 2013). Health care services are also characterized by a high level of interaction between a service provider and a customer, i.e. a patient (Chang et al., 2013; Jameel et al., 2019) and high customer involvement (Padma et al., 2010; Pevec \& Pisnik, 2018). Therefore, behaviour of front-line personnel in a health care setting significantly shapes customers' perceptions of service quality and customer satisfaction. In service settings which require high interaction between the provider and a customer, like health care services, in addition to the behaviour of front line personnel, researchers have also accentuated the importance of physical environment where service production and consumption takes place (Padma et al., 2010; Chang et al., 2013), as well as patients' actions, moods and willingness to cooperate (Naidu, 2009). Intangible nature of health care services leads to customers' inability to predict the outcome of a service provision and also 
imposes a high level of risk and uncertainty. Health care services are rich in credence attributes, which makes it difficult for a patient to evaluate these services even after the provision of services (Upadhyai et al., 2019).

Moreover, patients co-create value of health care services, but lack knowledge to assess medical personnel' skills and competencies (Amin \& Nasharuddin, 2013; Satsanguan et al., 2015; Adomah-Afari et al., 2019). Due to information asymmetry between health care providers and patients, trust is regarded as a key aspect of provideruser relationship (Barile et al., 2014). Closely related to the information asymmetry is an agency relationship in a health care, which implies that a principal, i.e. a patient, delegates authority to an agent, i.e. a physician, who becomes responsible for making decisions in patient's best interest (Folland et al., 2017). When it comes to credence services, quality of interaction significantly shapes customers' perceptions of service quality, i.e. service personnel who are friendly, polite and show empathy towards customers are considered crucial drivers of customer satisfaction (Choi \& Kim, 2013; Naik Jandavath \& Byram, 2016).

The establishment of a relationship between service provider and a customer is particularly important in health care services, due to the relevance and complexity of health care services (Berry et al., 2008; Naidu, 2009; Chang et al., 2013; Huynh \& Dicke-Bohmann, 2020). As patients lack skills to evaluate technical quality of health care services, according to Alrubaiee and Alkaa'ida (2011) they rely on interpersonal relations to infer quality judgments.

\subsection{Health care service quality}

In a health care setting, service quality is defined as the gap between patients' perceptions of received service and his expectations of the service (Woodside et al., 1989). Parasuraman et al. (1988) proposed a 22-item measurement scale, SERVQUAL, according to which service quality can be calculated as a gap between customer perceptions and expectations along five dimensions of service quality, such as reliability, responsiveness, assurance, empathy and tangibility. Since its introduction in 1988, SERVQUAL has become the most widely applied instrument for service quality measurement across service industries, including health care. It is important to understand how patients evaluate health care service quality as it is expected to improve the outcome of a health care system and enhance patient perceptions of service quality (Amin \& Nasharuddin, 2013). Perceptions which surpass patient's expectations lead to patient's satisfaction (Pevec \& Pisnik, 2018), which is expected to contribute to patients' willingness to use services of the same institution again and recommend the institution (Naik Jandavath \& Byram, 2016).

In spite of several successful applications of SERVQUAL scale in health care settings, it has been criticized on numerous conceptual and methodological issues (Alrubaiee \& Alkaa'ida, 2011), due to which various measurement instruments, claimed to be appropriate for health care setting, have been proposed.

In the context of health care services in India, Padma et al. (2010) studied patients' and their attendants' perceptions of service quality and found out eight dimensions of service quality, such as: administrative 
procedures, safety indicators, infrastructure, patients' friends and family, physical process of clinical care, personnel quality, surrounding, admission and discharge hospital image, social responsibility, and trustworthiness of the hospital. Grøndahl et al.'s (2018) study of patients' perceptions of care quality in Norwegian health care setting indicated the following four quality dimensions: physical-technical conditions in a hospital, medical competence of personnel, identity-oriented approach to patients and sociocultural atmosphere in a hospital. Studying patients' perceptions of service quality in public and private hospitals in Northern Cyprus, Arasli et al. (2008) found out six dimensions of service quality, such as: medical personnel' empathy for patients, medical personnel' concern for patients' needs, relationships between personnel and patients, doctors' professionalism, quality of food and quality of physical environment, whereas empathy emerged as the most important quality dimension. Jabnoun and Chaker (2003) pointed out that patients' perceptions of health care service quality in the United Arab Emirates were influenced by their evaluation of reliability, empathy, tangibles, administrative responsiveness and supporting skills, whereas reliability emerged as the most significant dimension of service quality. Sumaedi et al. (2016) have highlighted the quality of health care delivery, health care personnel, health care resources and administrative procedures as the main dimensions of service quality in Indonesian public health care setting. Amin and Nasharuddin's (2013) study in Malaysian health care setting revealed overall service, medical service, social responsibility, admission and discharge as the main components of health care service quality. Research findings stemming from the U.S. health care setting point to the care of nurses, physician care, compassion to process as the main constituents of service quality (Otani \& Kurz, 2004). Jameel et al.'s (2019) study in public sector hospitals in Pakistan indicated five-dimensional structure of service quality, comprising the following dimensions: physical infrastructure quality, provider-patient interactional quality, administrative quality, medical care quality and nursing care quality. Senic and Marinkovic's (2013) study in the context of student polyclinic in Serbian health care setting indicated three dimensions of service quality, such as personal relationships, promptness and tangibility. Marković et al.'s (2014) study resulted in four dimensions of health care service quality in Croatian health system, such as staff communication and reliability, assurance, output quality and hospital environment. Another study performed in Croatia, in a primary health care setting, revealed three dimensions of service quality, such as tangibility, assurance and the combination of reliability, responsiveness and empathy (Mečev \& Kardum Goleš, 2015).

Recent review of health care service quality measurement instruments indicates that various dimensions of health care service quality have emerged from different studies and that a universally accepted measurement scale for health care setting has not been agreed upon (Upadhyai et al., 2019), although common measurement items and service quality dimensions of similar content prevail in previous research.

This study will apply Choi et al.'s (2004) health care service quality measurement instrument, due to its impact on later research in health care settings and the fact that the instrument has been also validated in 
Serbian health care setting (Rajić et al., 2020). According to this approach, health care service quality is a four-dimensional construct, whereas patients' overall quality perceptions are based on their evaluation of doctors' concern, concern of other medical personnel, convenience of medical procedures and tangibles.

\subsection{Perceived value of health care services}

Perceived value is generally regarded as one of the key aspects of consumer experience, however, in comparison with service quality and satisfaction, it has unjustifiably received far less research attention (Pevec \& Pisnik, 2017). When it comes to health care services, the delivery of superior value to patients and patient satisfaction have been recognized as primary objectives of contemporary health care systems (Materla et al., 2019).

In service settings which imply high customer involvement, as is the case with health care services, perceived value of services is of particular importance (Pevec \& Pisnik, 2018). In health care settings, customers, i.e. patients, simultaneously participate in production and consumption of health care services and together with service providers they co-create value of health care services (Padma et al., 2010). A vast number of studies has mainly focused on Zeithaml's (1988) conceptualization of perceived value, according to which perceived value is a trade-off between the benefits one acquires and a sacrifice he/she has to undergo to obtain a good or a service. Alrubaiee and Alkaa'ida (2011) suggest relatedness among perceived value and patient satisfaction by explaining patient satisfaction as "an attitudinal response to value judgments that patients make about their clinical encounter" (p.106). According to Naidu (2009) the provision of appropriate information and the expression of care and concern for customers by health care personnel positively contribute to patient value perceptions, whereas high costs of health care services diminish patient's level of satisfaction. Although perceived value of health care services has not been thoroughly examined in previous research, the literature holds that perceived value is an antecedent to customer satisfaction (Moliner, 2009).

\subsection{Patient satisfaction}

Customer satisfaction has been attracting researchers' attention for decades. According to one of the most frequently cited definitions of customer satisfaction, "it is a judgment that a product/service feature, or the product or service itself, provided (or is providing) a pleasurable level of consumption-related fulfillment, including levels of under- or overfulfillment" (Oliver, 1997; p.13). Positive interaction between a physician and a patient is generally acknowledged as the most important prerequisite for patient satisfaction and patient satisfaction is regarded as a fundamental requirement for the establishment of long-term relationships between a health care institution and patients (Naik Jandavath \& Byram, 2016). Health care providers who are competent, approachable, kind, courteous and friendly make patients satisfied ( $\mathrm{Ng} \&$ Luk, 2020). Satisfied patients are expected to continue using services of the same health care institution in the future, when a new related treatment is needed, and recommend the institution to their peers (Jameel et al., 2019). However, if a patient has to wait longer for 
an appointment it may prevent him from using services of a chosen institution (Roy et al., 2020). Taking into account the relevance of patient satisfaction for future performance of health care institutions, Sumaedi et al. (2016) have called for the development of patient satisfaction index, as a means for measuring, monitoring and improving patients' overall satisfaction.

\subsection{Patient trust in a health care provider}

Customer trust has been praised by scholars as a factor which reduces customer churn and leads to the establishment of longterm relationships among exchange partners (Chang et al., 2013). Trust is especially relevant in exchange relations which imply high level of perceived risk, such as health care relations (Sousa \& Alves, 2019). In a health care context, trust can be explained as a patient's belief that he/she can rely on a health care provider to deliver on its promises, i.e. patient trust is a confidence in health care provider's reliability and integrity (Alrubaiee \& Alkaa'ida, 2011). It is regarded as a key component in patientphysician relationship as trust can reduce patient's burden and difficulty in completing care-related tasks (Bonds et al., 2004; Hillen et al., 2013) and contribute to the improvement of patient's health (Chandra et al., 2018). Patients who trust a physician are willing to adhere to prescribed therapy and therewith facilitate the healing process (Crits-Christoph et al., 2019). Trust in a health care setting has been shown to evolve from patients' positive perceptions of a physician's honesty, ability to convey competence, benevolence, fidelity, caring attitude and sincerity (Berry et al., 2008; Hillen et al., 2012; Hillen et al., 2014).
Literature posits that the higher the level of customer satisfaction, the greater the trust into an exchange partner (Moliner, 2009). Trust in a health care provider has been reported to lead to patients' willingness to complete suggested screening procedure (Gupta et al., 2014). It has been also shown to positively influence physical healthrelated quality of life of patients suffering from a chronic illness (Lee \& Lin, 2011).

However, it has been also stated that patient's naive trust in a physician's knowledge and competency, i.e. patient's inability to recognize the importance of his own active participation in a healing process, can have adverse effects on health outcomes (Lee \& Lin, 2011).

\subsection{Patient commitment to a health care provider}

Commitment has been recognized as a key ingredient of successful long-term relationships (Kim et al., 2008). Morgan and Hunt (1994) explained relationship commitment as a desire of an exchange partner to continue a relationship with the other party, due to his belief in the worthiness of a relationship, which as such warrants the investment of efforts to endure the relationship indefinitely. According to Moliner (2009), commitment is "the highest level of relational bond" (p. 80) and implies a willingness of an exchange partner to make short-term sacrifices in order to achieve long-term benefits. Patient commitment to a health care provider and patient loyalty are regarded as close, however, different constructs (Moreira \& Silva, 2015). Patient satisfaction is regarded as a key prerequisite for the continuance of cooperation between a patient and a health care provider (AdomahAfari et al., 2019). In addition to satisfaction, 
trust has also been shown to lead to patient commitment to a health care provider (Berry et al., 2008). Commitment to a service provider has been recognized as an antecedent to customer loyalty in service settings (Lai, 2014; Sousa \& Alves, 2019).

\subsection{Hypotheses}

Moreira and Silva (2015) have reported significant impact of service quality on patient satisfaction in Portuguese private health care setting. A number of additional investigations across health care settings have indicated the antecedent role of service quality to patient satisfaction (Otani \& Kurz, 2004; Padma et al., 2010; Amin \& Nasharuddin, 2013; Naik Jandavath \& Byram, 2016; Sumaedi et al., 2016; Aljaberi et al., 2018). Previous research has also pointed to the relevance of sociodemographic factors, such as age, education, social class, income, health and marital status, for shaping patient level of satisfaction with health care services (Naidu, 2009). Based on these prior findings, it is hypothesized in Serbian health care setting that:

H1: Health care service quality has significant effect on patient satisfaction.

Sumaedi et al.'s (2016) study in Indonesian health care setting provided evidence of significant positive effect of perceived value of health care services on patient satisfaction. Perceived value also emerged as a significant predictor of patient satisfaction in Moliner's (2009) and Boakye et al.'s (2017) studies. Pevec and Pisnik (2018) examined the antecedents and consequences of perceived value of health care services in Slovenian health care setting. Their study indicated significant impact of service quality on perceived value and the contribution of both quality and value to patients' satisfaction. Significant impact of health care service quality on perceived value has been also supported by Boakye et al. (2017). Therefore, the following hypotheses are proposed:

H2: Perceived value of health care services directly influences patient satisfaction;

H3: Health care service quality directly affects perceived value.

Jameel et al.'s (2019) study on a sample of Pakistani patients of public health care institutions has indicated significant impact of patient satisfaction on their willingness to continue treatment at the same clinic, use services of the same clinic, if needed, and recommend the clinic to other patients. Improvements in patient satisfaction have been shown to lead to favourable behavioural intentions of patients in a number of empirical studies (Kim et al., 2008; Amin \& Nasharuddin, 2013; Choi \& Kim, 2013; Naik Jandavath \& Byram, 2016; Aljaberi et al., 2018; Meesala \& Paul, 2018). In view of these prior findings, the following hypothesis is proposed:

H4: Patient satisfaction directly affects patient behavioural intentions.

Besides direct relatedness among
satisfaction and service customer
behavioural intentions, extant literature
indicates the mediating roles of trust and
commitment in a relationship between
satisfaction and behavioural intentions. In a
study of patients' perceptions of health care 
services in Jordan, Alrubaiee and Alkaa'ida (2011) provided evidence of significant impact of quality perceptions and satisfaction on patients' trust into a provider of medical services. Hillen et al.'s (2012; 2013) studies in the Netherlands and Australia indicated significant correlations among patients' satisfaction, trust in a physician and patient's willingness to recommend the physician. Patient satisfaction emerged as significant determinant of trust in Moreira and Silva's (2015) study in Portuguese health care setting. Empirical research from the Spanish health care setting also provided evidence of significant impact of patient satisfaction on trust in a health care provider (Moliner, 2009). Besides the antecedent role of satisfaction to trust in a service provider, review of literature indicates that the quality of interaction between health care personnel and patients is positively related to patients' trust and satisfaction (Chandra et al., 2018). Berry et al.'s (2008) study, performed on a large sample of patients of four clinics in Texas, indicates that trust in a physician is influenced by a physician's knowledge of a patient and patient's medical history, medical competence of a physician and willingness of a physician to listen, understand a patient and encourage a patient to ask questions (Berry et al., 2008), which are the aspects of service delivery which have been generally acknowledged in previous studies as service quality attributes. A Taiwanese study has provided support for significant positive effect of service quality on patient satisfaction and trust in a physician (Chang et al., 2013). Recent research has also shown significant impact of clinician humility, i.e. the ability to listen to and express concern for patients, on patient trust in the doctor (Huynh \& Dicke-Bohmann, 2020). Trust in a physician has been shown to enhance patients' willingness to recommend the physician to other people who need medical care and confidence in the success of the proposed surgery (Hillen et al., 2014). The antecedent role of trust to patient loyalty was also supported in Moreira and Silva's (2015) study in Portuguese health care setting. Based on these findings, we propose the following hypotheses:

H5: Patient satisfaction has significant effect on trust in a health care provider;

H6: Trust in a health care provider is directly affected by patient's perceptions of health care service quality;

H7: Trust in a provider has significant effect on patient behavioural intentions.

Sousa and Alves (2019) posit that trust in an exchange partner reduces perceived risk and vulnerability, providing foundation for the establishment and maintenance of longterm relations. Berry et al. (2008) provided evidence of a significant impact of trust in a physician on relationship commitment. Significant impact of trust on patient commitment also emerged in Moreira and Silva's (2015) research in Portuguese health care setting. Both trust and satisfaction emerged as significant predictors of patient commitment to a hospital in an empirical investigation in Spanish health care setting (Moliner, 2009). In Kim et al.'s (2008) study in South Korean health care setting patients' relationship commitment emerged as a significant antecedent to brand loyalty. In view of these prior findings, it is hypothesized that: 
H8: Trust in a provider significantly affects patient commitment to the provider;

H9: Patient satisfaction is a direct determinant of commitment to the health care provider;

H10: Commitment to a health care provider directly affects patient behavioural intentions.

Conceptual model which integrates hypothesized relationships is presented in Figure 1.

\section{METHODOLOGY}

\subsection{Sample and data collection}

Data collection was carried out on a convenience sample of patients, by means of self-administered questionnaire. The questionnaires were distributed to respondents present in the waiting room of a primary health care institution, who came to visit their chosen general practitioner and who were willing to participate in anonymous study. Although anonymity of data collection secluded the possibility of further qualitative investigation of obtained quantitative research findings, it was a preferred option for data collection in order to reduce the occurence of a common method bias (Podsakoff et al., 2012), taking into consideration the sensitivity of this study's topic to the provision of sociallydesirable responses and the fact that both independent and dependent constructs were measured on the same sample of respondents. After excluding incomplete questionnaires from the sample, data analyses were performed on a total pool of 300 responses.

\subsection{Measurement instrument}

Items relating to service quality were adapted from the study of Choi et al. (2004), whereas the validity of this measurement instrument, which was developed in South Korean health care setting, has already been supported in Serbian health care context (Rajić et al., 2020). In accordance with the results of the aforementioned study which was conducted in Serbian health care setting, items related to service quality attributes were condensed into the following four dimensions of health care service quality: doctors' concern for patients, concern of

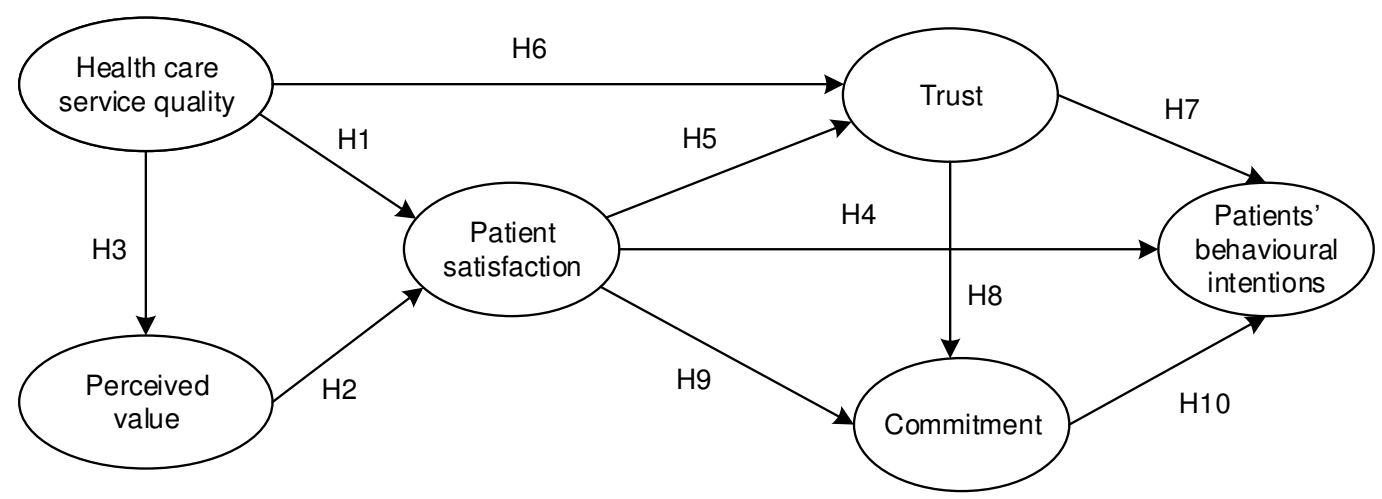

Figure 1. Conceptual model 
supportive health care personnel, convenience of medical process and tangible characteristics of a health care organization. Customer satisfaction was measured with two items, adjusted from the study of Pevec and Pisnik (2017). To indicate their level of satisfaction, respondents were asked to rate their general level of satisfaction with services received from the particular health care organization and to rate their level of satisfaction with the decision to use services of the particular health care organization. Two items were used to measure perceived value, and these were proposed in accordance with Moliner's (2009) conceptualization of monetary and nonmonetary costs. Respondents were asked to indicate the extent to which they regarded monetary and non-monetary costs of health care as well worth it. To measure patients' trust in a health care provider four items were used, which were proposed in line with Morgan and Hunt's (1994) conceptualization of trust. Respondents were asked to indicate the extent to which they trust a health care provider to take care of their best interests, their confidence in a health care provider, the extent to which they regarded a health care provider as reliable and having high integrity. Commitment to a health care provider was measured with three items adapted from the study of Moliner (2009). To indicate their level of commitment to a health care provider respondents were asked to rate the health care provider's capacity to meet its obligations towards patients, in terms of skills and resources, and to indicate their agreement with the statement that experience with the health care provider has always been a positive one and whether they felt at ease with the health care provider. Three items adapted from the work of Pevec and Pisnik (2017) were used to measure patients' behavioural intentions. Respondents were asked to indicate the extent to which they have a positive opinion about the health care provider, whether they would recommend the provider and the likelihood of using services of the same provider in the future.

Items were measured on a five-point Likert-type scale, ranging from 1-strongly disagree to 5-strongly agree. Qualitative research, in the form of focus group discussions, preceded quantitative research. Group discussion participants were asked to provide feedback on the readability of questionnaire items, on the grounds of which several items were refined.

\subsection{Analyses}

Conceptual framework of the study was examined adherring to a two-step procedure recommended by Anderson and Gerbing (1988). Measurement model, reliability and validity of proposed constructs were examined first, upon which structural relationships were analyzed. To calculate total impact of one latent variable on another, a bootstrapping procedure was applied. Data analyses were performed using SPSS v.17 and AMOS V.16.

\section{RESULTS}

\subsection{Sample characteristics}

Male and female respondents were almost equally represented in the sample (51\% vs. $49 \%$ ). The majority of respondents were in the age groups $45-54(24 \%)$ and $35-44$ $(23 \%)$, followed by the age group 55-64 $(21.3 \%)$ and $25-34$ (17.7\%). Urban area inhabitants were the majority of respondents 
(78\%). According to the employment of respondents, the most represented were respondents employed in public organizations $(36.3 \%)$, followed by other place and mode of employment (25.3\%). Housekeeper or a housewife was the third most represented category of respondents $(13.3 \%)$.

\subsection{Measurement analysis}

Confirmatory factor analysis was applied to determine fitting of the measurement model and examine validity of the constructs. Satisfactory fit of the model to the data was indicated by fit indices which were within the range of recommended values (Milošević et al., 2019), such as $\chi^{2} / d f=3.26, \quad$ CFI $=0.951, \quad$ TLI $=0.938$,
$\mathrm{NFI}=0.931, \mathrm{RMSEA}=0.08$.

Convergent validity was supported as $\mathrm{t}$ values corresponding to factor loadings of measurement items reached the level of statistical significance $(p<0.05)$ and average variance extracted (AVE) of each latent construct exceeded recommended threshold of 0.50. Moreover, construct reliability values of all latent variables exceeded the level of 0.70 . Cronbach's alpha values of all latent variables exceeded the value of 0.70 , as displayed in Table 1, and as such indicated internal consistency of the constructs (Hair et al., 2010).

Discriminant validity was examined by comparing AVE values of each pair of constructs with squarred correlation among the constructs and, as AVEs exceeded squarred correlations, evidence was provided

Table 1. Measurement model results

\begin{tabular}{|c|c|c|c|c|}
\hline Constructs and items & $\begin{array}{l}\text { Standardized } \\
\text { factor loadings }\end{array}$ & t-value & $\begin{array}{l}\text { Construct } \\
\text { reliability }\end{array}$ & $\begin{array}{l}\text { Cronbach's } \\
\text { alpha }\end{array}$ \\
\hline Health care service quality & & & 0.854 & 0.847 \\
\hline SQ1 & 749 & - & & \\
\hline SQ2 & .826 & 14.658 & & \\
\hline SQ3 & .806 & 14.256 & & \\
\hline SQ4 & .698 & 12.151 & & \\
\hline Perceived value & & & 0.803 & $0.784 *$ \\
\hline V1 & 937 & - & & \\
\hline $\mathrm{V} 2$ & .688 & 13.738 & & \\
\hline Patient satisfaction & & & 0.926 & $0.926^{*}$ \\
\hline $\mathrm{S} 1$ & .921 & - & & \\
\hline $\mathrm{S} 2$ & .936 & 27.825 & & \\
\hline Patient trust & & & 0.932 & 0.946 \\
\hline $\mathrm{T} 1$ & .933 & - & & \\
\hline $\mathrm{T} 2$ & .936 & 29.582 & & \\
\hline T3 & .840 & 22.011 & & \\
\hline $\mathrm{T} 4$ & .803 & 19.877 & & \\
\hline Patient commitment & & & 0.909 & 0.920 \\
\hline $\mathrm{C} 1$ & 961 & - & & \\
\hline $\mathrm{C} 2$ & .928 & 29.952 & & \\
\hline $\mathrm{C} 3$ & .710 & 16.049 & & \\
\hline Patients' behavioural intentions & & & 0.958 & 0.957 \\
\hline BI1 & .952 & - & & \\
\hline BI2 & .925 & 31.956 & & \\
\hline BI3 & .942 & 34.432 & & \\
\hline
\end{tabular}


in support of discriminant validity, as shown in Table 2, where values on the diagonal represent AVEs and off-diagonal values correspond to squarred correlations among constructs.

\subsection{Structural analysis}

Upon the establishment of the acceptable fit of the measurement model, structural equation modelling (SEM) was applied to examine hypothesized relationships. Acceptable fit of the structural model to the data was indicated by the following values of fit indices: $\quad \chi^{2} / d f=3.24, \quad \mathrm{CFI}=0.949$, TLI $=0.938$, NFI $=0.929$, RMSEA $=0.08$.

Taking into account satisfactory fit of the structural model, hypothesized relationships were examined in the following stage. Results of the study indicate significant direct effect of health care service quality and perceived value on patient satisfaction, which emerged as a significant direct predictor of patients' behavioural intentions. Unlike trust into a health care provider, commitment emerged as a significant direct antecedent to patients' behavioural intentions, as presented in Table 3.

In addition to direct relationships, findings of the study revealed significant indirect relationships among the constructs. The impact of health care service quality on patient satisfaction is also mediated via perceived value of health care services. The application of maximum likelihood bootstrapping, with 1000 bootstrap samples and $95 \%$ bias-corrected confidence intervals, resulted in statistically significant $(p<.01)$ total effect of health care service quality on patient satisfaction of 0.822 , implying

Table 2. Discriminant validity

\begin{tabular}{lcccccc}
\hline & $\begin{array}{l}\text { Health care } \\
\text { service quality }\end{array}$ & $\begin{array}{l}\text { Perceived } \\
\text { value }\end{array}$ & Satisfaction & Trust & Commitment & $\begin{array}{l}\text { Behavioural } \\
\text { intentions }\end{array}$ \\
\hline Health care service quality & 0.594 & & & & & \\
Perceived value & 0.540 & 0.676 & & & & \\
Satisfaction & 0.547 & 0.543 & 0.862 & & & \\
Trust & 0.528 & 0.339 & 0.348 & 0.774 & & \\
Commitment & 0.579 & 0.458 & 0.512 & 0.550 & 0.763 & \\
Behavioural intentions & 0.573 & 0.540 & 0.736 & 0.4 & 0.615 & 0.883 \\
\hline
\end{tabular}

Table 3. Results of structural analysis

\begin{tabular}{lccl}
\hline Hypotheses & $\begin{array}{c}\text { Standardized } \\
\text { estimates }\end{array}$ & t-values & $\begin{array}{l}\text { Results of } \\
\text { hypothesis testing }\end{array}$ \\
\hline H1: Service quality $\rightarrow$ Patient satisfaction & 0.281 & 2.440 & Supported \\
H2: Perceived value $\rightarrow$ Patient satisfaction & 0.631 & 5.122 & Supported \\
H3: Service quality $\rightarrow$ Perceived value & 0.856 & 14.026 & Supported \\
H4: Satisfaction $\rightarrow$ Patients' behavioural intentions & 0.722 & 14.545 & Supported \\
H5: Satisfaction $\rightarrow$ Trust & -0.113 & -1.198 & Not supported \\
H6: Service quality $\rightarrow$ Trust & 0.912 & 8.449 & Supported \\
H7: Trust $\rightarrow$ Patients' behavioural intentions & 0.071 & 1.796 & Not supported \\
H8: Trust $\rightarrow$ Commitment & 0.317 & 5.583 & Supported \\
H9: Satisfaction $\rightarrow$ Commitment & 0.526 & 9.028 & Supported \\
H10: Commitment $\rightarrow$ Patients' behavioural intentions & 0.211 & 4.669 & Supported \\
\hline
\end{tabular}


stronger effect of service quality on satisfaction, in comparison with perceived value. Although the direct impact of trust on patients' behavioural intentions was not statistically significant $(p>.05)$, taking into account its total effect on patients' future intentions $(\beta=.138, p<.01)$, mediated via commitment, trust should not be neglected as a determinant of patients' future intentions. In terms of total effect on patients' behavioural intentions, satisfaction emerged as the most influential determinant of intentions $(\beta=.818, p<.01)$, followed by health care service quality $(\beta=.798, p<.01)$, perceived value $(\beta=.516, \quad p<.01)$, commitment $(\beta=.211, p<.01)$ and trust $(\beta=.138, p<.01)$.

\section{DISCUSSION}

Taking into account the relevance of customer satisfaction for enhancing positive intentions of customers in service business, especially those faced with increasing competitive pressures, such as health care industry, the objective of this research was to propose a patient satisfaction model, building upon extant research in service businesses, and examine the determinants of satisfaction and their contribution to patient satisfaction and the impact of satisfaction, trust and commitment on patients' behavioural intentions. As available empirical findings of the determinants and effects of patient satisfaction mainly stem the U.S. and studies performed in Western (the Netherlands) and South-Western (Paortugal, Span, Italy), i.e. advanced European economies, Serbian health care setting was chosen as the context of this study, with the aim to enlarge existing knowledge on patient satisfaction and provide managerially relevant directions for health care administrators.

Findings of this study imply that by the improvement of health care service quality perceptions of value of health care services arise and both of these constructs lead to the enhancement of patient satisfaction, which provided support for $\mathrm{H} 1, \mathrm{H} 2, \mathrm{H} 3$. Choi et al's (2004) study in the South Korean health care setting also corroborated these findings. In addition to enhancing patient satifaction, improvement of health care service quality enhances patient trust into a health care provider, which provided support for hypothesis H6. This finding has been also supported in previous research (Chang et al., 2013).

In terms of direct effect, satisfaction and commitment emerged as significant determinants of patients' behavioural intentions, whereas satisfaction exerted stronger influence on patients' future intentions. Therewith, support has been provided to hypotheses $\mathrm{H} 4$ and H10. Some recent studies have also indicated that patients who were satisfied with medical services received from a health care institution were also more inclined to use the services of the same institution in the future, if a need arised, and were also willing to recommend the institution to other prospective patients (Aljaberi et al., 2018; Jameel et al., 2019). In addition to significant direct influence of satisfaction on patients' behavioural intentions, its effect on future intentions of patients is also mediated via patient commitment, leading to a statistically significant $(p<.01)$ total effect of satisfaction on patients' behavioural intentions of .818. As indicated by this study's findings, the more satisfied a patient is, the more likely he/she is to continue relationship with a health care service 
provider, which supports hypothesis H9. Although structural analysis resulted in insignificant direct influence of patient satisfaction on patient trust into a health care provider $(p>.05)$ (H5) and insignificant direct relatedness between trust and patients' behavioural intentions ( $\mathrm{H} 7)$, the relevance of instilling trust into patients should not ne neglected by health care administrators, as investments into the establishment of patients' trust in a health care provider enhance patients' positive intentions by the improvement of patient commitment to a health care provider (H8). Based on the above discussion it can be concuded that hypotheses $\mathrm{H} 5$ and $\mathrm{H} 7$ are rejected, whereas hypothesis $\mathrm{H} 8$ is supported.

\section{CONCLUSION}

\subsection{Implications for theory and practice}

This study has been motivated by the paucity of empirical evidence, outside of the U.S., Western and South-Western European health care contexts, related to the factors that can enhance patient satisfaction and factors that can contribute to the overall impact of satisfaction on positive behavioural intentions of patients in the future. By indicating the mechanism of the enhancement of patients' future intentions, results of this study extend existing knowledge on the determinants and consequences of patients' satisfaction.

Results of this study also bear some important implications for health care administrators and policy-makers. The study's findings indicate that the improvement of service quality directly and indirectly, via perceived value, enhances patients' satisfaction, which directly and indirectly, via commitment, contributes to patients' favourable behavioural intentions. To make satisfied patients, medical institutions should provide health care services which exceed patient expectations and which are perceived by patients as providing benefits which surpass monetary and non-monetary sacrifice that a patient has to undergo to receive a treatment. Taking into consideration the relevance of overall quality perceptions for enhancing patient satisfaction, administrators of health care institution would benefit from a more precise knowledge on relative importance of health care quality dimensions for improving patient satisfaction. Moreover, health care managers would benefit from measuring health care personnel' perceptions of patients' expectations and perceptions of service quality. This would allow for timely insight into eventual gaps between service providers' and health care customers' perceptions and these gaps could be closed by initiating appropriate training programmes for health care staff and/or clarifying to patients what would be realistic to expect from a health care provider. Measurement of patient expectations and perceptions on a continuous basis, together with the knowledge on relative importance of health care service quality dimensions, would allow for better allocation of constrained financial resources for the improvement of medical institutions' operations.

Health care administrators are also advised to measure and monitor trust and commitment to a health care provider, which contribute to the total effect of satisfaction on patients' positive intentions towards a health care provider. 
6.2. Limitations and future research directions

One should be cautious in generalizing this study's findings, in the light of several limitations of the study. Sampling procedure and sample size are the main shortcomings of this study, taking into consideration that the study has been performed in primary health care setting, on a convenience sample of patients of only one public health care institution. To draw generalizable conclusions, future research should focus on probability sampling and more representative sample of users of Serbian health care services, as well as secondary and tertiary health care.
Another limitation of the study is its cross-sectional design. Thereupon, data collecection which was performed at one point in time precludes causal inferences to be drawn. To overcome this limitation, future research should be performed using longitudinal study design.

Pevec and Pisnik (2017) claim that reputation of a health care institution is one of the key factors which influence patients' choice of the institution whose medical services they will use. Patients' perceptions of reputation as a consequence of patients' experience with the institution and the contribution of reputation to patients' future intentions would merit further investigation. Taking into account previous research

\section{МОДЕЛОВАЊЕ САТИСФАКЦИЈЕ КОРИСНИКА ЗАДРАВСТВЕНИХ УСЛУГА: ПОДАЦИ ИЗ СРБИЈЕ}

\section{Тамара Рајић, Ана Ракић, Исидора Милошевић}

\section{Извод}

Лојалност корисника, са сатисфакцијом као својим главним предусловом, дуго се сматрају главним циљевима услужних бизниса. Са порастом броја пружаоца здравствених услуга, што је довело до пораста конкурентских притиска на тржишту, питање како задовољити и задржати пацијенте добија све више пажње међу истраживачима и менаџментом здравствених организација. Стога, ова студија има за циљ да испита детерминанте сатисфакције пацијената и директан и посредован утицај сатисфакције на намеравано понашање пацијената у контексту који је до сада недовољно истражен, као што је то здравствени систем у земљама у развоју. Студија је спроведена у контексту примарне здравствене заштите, на пригодном узорку од 300 пацијената, помоћу структурираног упитника. Применом моделовања помоћу структурних једначина (CEM) откривен је директан утицај квалитета здравствених услуга на сатисфакцију пацијената, као и посредован утицај квалитета услуга на сатисфакцију, путем перципиране вредности здравствених услуга. Поред директног утицаја задовољства на намеравано понашања пацијената, његов укупни утицај на позитивне намере пацијената повећава се утицајем посвећености пацијената здравственој установи, при чему се посвећеност пацијената, како показују налази ове студије, повећава са порастом поверења пацијената у здравствену установу. Теоријске и практичне импликације, које произилазе из овог истраживања, размотрене су у раду и наведене су смернице за даља истраживања.

Кључне речи: квалитет здравствених услуга, перципирана вредност, задовољство пацијената, поверење, посвећеност, намеравано понашање пацијената 
findings of the importance of demographic characteristics on the development of patient satisfaction (Naidu, 2009), it would be insightful to replicate this study enhancing proposed conceptual model with the moderating effects of demographic characteristics on the relationships between patient satisfaction and its determinants and outcomes.

\section{References}

Adomah-Afari, A., Mantey, D.D.D., \& Awuah-Werekoh, K. (2019). Factors influencing a long-term relationship between healthcare providers and patients perspectives of patients at a public regional hospital, Ghana. International Journal of Pharmaceutical and Healthcare Marketing, 13 (3), 364-386.

Aljaberi, M.A., Juni, M.H., Al-Maqtari, R.A., Lye, M.S., Saeed, M.A., Al-Dubai, S.A.R., \& Shahar, H.K. (2018). Relationships among perceived quality of healthcare services, satisfaction and behavioural intentions of international students in Kuala Lumpur, Malaysia: a cross-sectional study. BMJ Open, 8 (9), 021180 .

Alrubaiee, L., \& Alkaa'ida, F. (2011). The Mediating Effect of Patient Satisfaction in the Patients' Perceptions of Healthcare Quality - Patient Trust Relationship. International Journal of Marketing Studies, 3 (1), 103-127.

Amin, M., \& Nasharuddin, S.Z. (2013). Hospital service quality and its effects on patient satisfaction and behavioural intention. Clinical Governance: An International Journal, 18 (3), 238-254.

Anderson, J.C., \& Gerbing, D.W. (1988). Structural equation modeling in practice: A review and recommended two-step approach. Psychological Bulletin, 103 (3), 411-423.

Arasli, H., Ekiz, E.H., \& Katircioglu, S.T. (2008). Gearing service quality into public and private hospitals in small islands: Empirical evidence from Cyprus. International Journal of Health Care Quality Assurance, 21 (1), 8-23.

Barile, S., Saviano, M., \& Polese, F. (2014). Information asymmetry and cocreation in health care services. Australasian Marketing Journal, 22 (3), 205-217.

Berry, L.L., Turner, P.J., Janakiraman, R., Ogburn-Russell, L., Couchman, G.R., Rayburn, W.L., \& Grisel, J. (2008). Patients' Commitment to Their Primary Physician and Why It Matters. Annals of Family Medicine, 6 (1), 6-13.

Boakye, K.G., Blankson, C., Prybutok, V.R., \& Qin, H. (2017). An assessment of national healthcare service delivery: a Ghanaian illustration. International Journal of Quality \& Reliability Management, 34 (5), 649-666.

Bonds, D.E., Camacho, F., Bell, R.A., Duren-Winfield, V.T., Anderson, R.T. \& Goff, D.C. (2004). The association of patient trust and self-care among patients with diabetes mellitus. BMC Family Practice, 5, 26.

Caceres, R.C., \& Paparoidamis, N.G. (2007). Service quality, relationship satisfaction, trust, commitment and business-to-business loyalty. European Journal of Marketing, 41 (7/8), 836-867.

Chandra, S., Mohammadnezhad, M., \& Ward, P. (2018). Trust and Communication in a Doctor-Patient Relationship: A Literature Review. Journal of Healthcare Communication, 3 (3), 1-6.

Chang, C-S., Chen, S-Y., \& Lan, Y-T. (2013). Service quality, trust, and patient 
satisfaction in interpersonal-based medical service encounters. BMC Health Services Research, 13, 22.

Choi, B.J., \& Kim, H.S. (2013). The impact of outcome quality, interaction quality, and peer-to-peer quality on customer satisfaction with a hospital service. Managing Service Quality, 23 (3), 188-204.

Choi, K., Cho, W., Lee, S., Lee, H., \& Kim, C. (2004). The relationships among quality, value, satisfaction and behavioral intention in health care provider choice: A South Korean study. Journal of Business Research, 57, 913-921.

Chung, K.-H., \& Shin, J.-I. (2010). The antecedents and consequents of relationship quality in internet shopping. Asia Pacific Journal of Marketing and Logistics, 22 (4), 473-491.

Crits-Christoph, P., Rieger, A., Gaines, A., \& Gibbons, M.B.C. (2019). Trust and respect in the patient-clinician relationship: preliminary development of a new scale. BMC Psychology, 7, 91.

Dang, B.N., Westbrook, R.A., Black, W.C., Rodriguez-Barradas, M.C., \& Giordano, T.P. (2013). Examining the Link between Patient Satisfaction and Adherence to HIV Care: A Structural Equation Model. PLoS ONE 8(1), 54729

Drury, A., Payne, S., \& Brady, A. (2020). Identifying associations between quality of life outcomes and healthcare-related variables among colorectal cancer survivors: A cross-sectional survey study. International Journal of Nursing Studies, 101, 103434.

Folland, S., Goodman, A.C., \& Stano, M., (2017).The Economics of Health and Health Care, International Edition, 8th Edition, Routledge, London and New York.

Grøndahl, V.A., Kirchhoff, J.W., Andersen, K.L., Sørby, L.A., Andreassen, H.M., Skaug, E., Roos, A.K., Tvete, L.S., \&
Helgesen, A.K. (2018), Health care quality from the patients' perspective: a comparative study between an old and a new, high-tech hospital. Journal of Multidisciplinary Healthcare, 11, 591-600.

Gupta, S., Brenner, A.T., Ratanawongsa, N., \& Inadomi, J.M. (2014). Patient Trust in Physician Influences Colorectal Cancer Screening in Low-Income Patients. American Journal of Preventive Medicine, 47 (4), 417-423.

Hair, J.F., Anderson, R.E., Tatham, R.L., \& Black, W.C. (2010). Multivariate Data Analysis: A Global Perspective (7th Edition). Pearson Prentice Hall. NY.

Hillen, M.A., Koning, C.C.E., Wilmink, J.W., Klinkenbijl, J.H.G., Eddes, E.H., Kallimanis-King, B.L., de Haes, J.C.J.M., \& Smets, E.M.A. (2012). Assessing cancer patients' trust in their oncologist: development and validation of the Trust in Oncologist Scale (TiOS). Support Care Cancer, 20 (8), 1787-1795.

Hillen, M.A., Butow, P.N., Tattersall, M.H.N., Hruby, G., Boyle, F.M., Vardy, J., Kallimanis-King, B.L., de Haes, H.C.J.M., \& Smets, E.M.A. (2013). Validation of the English version of the Trust in Oncologist Scale (TiOS). Patient Education and Counseling, 91 (1), 25-28.

Hillen, M.A., de Haes, H.C.J M., Stalpers, L.J.A., Klinkenbijl, J.H.G., Eddes, E.H., Butow, P.N., van der Vloodt, J., van Laarhoven, H.W.M., \& Smets E.M.A. (2014). How can communication by oncologists enhance patients' trust?, An experimental study. Annals of Oncology, 25 (4), 896-901.

Huynh, H.P., \& Dicke-Bohmann, A. (2020). Humble doctors, healthy patients? Exploring the relationships between clinician humility and patient satisfaction, trust, and health status. Patient Education 
and Counseling, 103 (1), 173-179.

Jabnoun, N., \& Chaker, M. (2003).

Comparing the quality of private and public hospitals. Managing Service Quality, 13 (4), 290-299.

Jameel, A., Asif, M., Hussain, A., Hwang, J., Bukhari, M.H., Mubeen, S., \& Kim, I. (2019). Improving Patient behavioral Consent through Different Service Quality Dimensions: Assessing the Mediating Role of Patient Satisfaction. International Journal of Environmental Research and Public Health, 16 (23), 4736.

Kim, W.G., Lee, Y.-K., \& Yoo, Y.-J. (2006). Predictors of relationship quality and relationship outcomes in luxury restaurants. Journal of Hospitality \& Tourism Research, 30 (2), 143-169.

Kim, K.H., Kim, K.S., Kim, D.Y., Kim, J.H., \& Kang, S.H. (2008). Brand equity in hospital marketing, Journal of Business Research, 61 (1), 75-82.

Lai, I.K.W. (2014). The Role of Service Quality, Perceived Value, and Relationship Quality in Enhancing Customer Loyalty in the Travel Agency Sector. Journal of Travel \& Tourism Marketing, 31 (3), 417-442.

Lee, Y.-Y., \& Lin, J.L. (2011). How much does trust really matter? A study of the longitudinal effects of trust and decisionmaking preferences on diabetic patient outcomes. Patient Education and Counseling, 85 (3), 406-412.

Marković, S., Lončarić, D., \& Lončarić, D. (2014). Service quality and customer satisfaction in the health care industry Towards health tourism market, Tourism and Hospitality Management, 20 (2), 155-170.

Martin, L.R., Feig, C., Maksoudian, C.R., Wysong, K., \& Faasse, K. (2018). A perspective on nonadherence to drug therapy: psychological barriers and strategies to overcome nonadherence. Patient
Preference and Adherence, 12, 1527-1535.

Materla, T., Cudney, E.A., \& Hopen, D. (2019). Evaluating factors affecting patient satisfaction using the Kano model. International Journal of Health Care Quality Assurance, 32 (1), 137-151.

Mečev, D., \& Kardum Goleš, I. (2015) Primary healthcare service quality measurement: Servqual scale. Ekonomski Vjesnik, 28, 161-177.

Meesala, A., \& Paul, J. (2018). Service quality, consumer satisfaction and loyalty in hospitals: Thinking for the future. Journal of Retailing and Consumer Services, 40, 261269.

Milošević, I., Mihajlović, I., \& Stojanović, A. (2019). Dominant factors of SMEs failure - multigroup confirmatory factor analysis. Serbian Journal of Management, 14 (2), 345 - 360.

Moliner, M.A. (2009). Loyalty, perceived value and relationship quality in healthcare services. Journal of Service Management, 20 (1), 76-97.

Moreira, A.C., \& Silva, P.M. (2015). The trust-commitment challenge in service quality-loyalty relationships. International Journal of Health Care Quality Assurance, 28 (3), 253-266.

Morgan, R.M. \& Hunt, S.D. (1994). The commitment-trust theory of relationship marketing. Journal of Marketing, 58 (3), 2038.

Naidu, A. (2009). Factors affecting patient satisfaction and healthcare quality. International Journal of Health Care Quality Assurance, 22 (4), 366-381.

Naik Jandavath, R.K., \& Byram, A. (2016). Healthcare service quality effect on patient satisfaction and behavioural intentions in corporate hospitals in India. International Journal of Pharmaceutical and Healthcare Marketing, 10 (1), 48-74. 
Ng, J.H.Y., \& Luk B.H.K. (2020). Patient satisfaction: Concept analysis in the healthcare context. Patient Education and Counseling, 102 (4), 790-796.

Oliver, R L. (1997). Satisfaction: A Behavioral Perspective on the Consumer. The McGraw-Hill Companies, Inc. New York.

Otani, K.A. \& Kurz, R.S. (2004). The impact of nursing care and other healthcare attributes on hospitalized patient satisfaction and behavioral intentions. Journal of Healthcare Management, 49 (3), 181-197.

Padma, P., Rajendran, C., \& Prakash, S.L. (2010). Service quality and its impact on customer satisfaction in Indian hospitals. Benchmarking: An International Journal, 17 (6), 807-841.

Parasuraman, A., Zeithaml, V.A., \& Berry, L.L. (1988). SERVQUAL: A multiple-item scale for measuring consumer perceptions of service quality. Journal of Retailing, 64 (1), 12-40.

Pevec, T., \& Pisnik, A. (2017). The development and validation of an evaluation system for patients' assessment of health services. Economic Thought and Practice, 2, 611-635.

Pevec, T., \& Pisnik, A. (2018). Empirical evaluation of a conceptual model for the perceived value of health services, Slovenian Journal of Public Health, 57 (4), 175-182.

Podsakoff, P.M., MacKenzie, S.B., \& Podsakoff, N.P. (2012). Sources of Method Bias in Social Science Research and Recommendations on How to Control It. Annual Review of Psychology, 63 (1), 539569.

Rajić, T., Milošević, I., \& Rakić, A. (2020). The Influential Factors of Health Care Customer Loyalty: Evidence from Serbia. Management: Journal Of Sustainable Business And Management Solutions In
Emerging Economies, 25 (2), 77-87.

Roy, P.J., Choib, S., Bernsteinc, E., \& Walleye, A. Y., (2020). Appointment waittimes and arrival for patients at a low-barrier access addiction clinic. Journal of Substance Abuse Treatment, 114, 108011

Satsanguan, L., Fongsuwan, W., \& Trimetsoontorn, J. (2015). Structural Equation Modelling of Service Quality and Corporate Image that affect Customer Satisfaction in Private Nursing Homes in the Bangkok Metropolitan Region. Research Journal of Business Management, 9 (1), 6887.

Senic, V., \& Marinkovic, V. (2013). Patient care, satisfaction and service quality in health care. International Journal of Consumer Studies, 37 (3), 312-319.

Sheppard, V.B., Wang, J., Yi, B., Harrison, T.M., Feng, S., Huerta, E.E., \& Mandelblatt, J.S. (2008). Are Health-care Relationships Important for Mammography Adherence in Latinas?. Journal of General Internal Medicine, 23 (12), 2024-2030.

Sousa, B.M., \& Alves, G.M. (2019). The role of relationship marketing in behavioural intentions of medical tourism services and guest experiences. Journal of Hospitality and Tourism Insights, 2 (3), 224-240.

Sumaedi, S., Bakti, I.G.M.Y., Rakhmawati, T., Astrini, N.J., Widianti, T., \& Yarmen M. (2016). Indonesian public healthcare service institution's patient satisfaction barometer (IPHSI-PSB), A new public healthcare patient satisfaction index. International Journal of Productivity and Performance Management, 65 (1), 25-41.

Tsai, T.C., Orav, E.J., \& Jha, A.H. (2015). Patient Satisfaction and Quality of Surgical Care in US Hospitals. Annals of Surgery, 261 (1), 2-8.

Upadhyai, R., Kumar, J.A., Roy, H., \& Pant, V. (2019). A Review of Healthcare 
Service Quality Dimensions and their

Measurement. Journal of Health

Management, 21 (1), 102-127.

Woodside, A,G., Frey, L.L., \& Daly, R.T. (1989). Linking service quality, customer satisfaction, and behavioural intention. Journal of Healthcare Marketing, 9 (4), 5-17. Zeithaml, V.A. (1988). Consumer perceptions of price, quality, and value: a means - end model and synthesis of evidence. Journal of Marketing, 52 (3), 222. 